ОСОБЛИВОСТІ ПРОФЕСІЙНОГО РОЗВИТКУ ПЕДАГОГІЧНИХ ПРАЦІВНИКІВ ЗАКЛАДІВ ФАХОВОЇ ПЕРЕДВИЩОЇ ОСВІТИ: ПРАВОВИЙ АСПЕКТ

\title{
PECULIARITIES OF PROFESSIONAL DEVELOPMENT OF PEDAGOGICAL EMPLOYEES OF PROFESSIONAL PRE-HIGHER EDUCATION INSTITUTIONS: THE LEGAL ASPECT
}

УДК 37.091

DOI https://doi.org/10.32843/2663$6085 / 2021 / 37.48$

\section{Курок P.O.,}

канд. юрид. наук, доцент,

молодший науковий співробітник Інституту професійно-технічної освіти Національної академії педагогічних наук України

\author{
Статтю присвячено дослідженню право- \\ вого забезпечення підвищення кваліфрікаціі \\ та стажування педагогічних працівників \\ закладів орахової передвищої освіти як \\ невід'ємного складника системи їх профе- \\ сійного розвитку. Установлено, що сучасні \\ умови здійснення освітньої діяльності зумов- \\ люють необхідність перегляду традичійних \\ підходів до просресійного розвитку педаго- \\ гічних працівників як із боку керівників закла- \\ дів освіти, так і з боку органів управління у \\ сорері освіти. Результатом цього процесу $\epsilon$ \\ внесення змін до чинного законодавства, що \\ регулює питання підвищення кваліфрікації та \\ стажування педагогів, із метою приведення \\ його до вимог вітчизняних та нормативно- \\ правових актів у сорері освіти. \\ Основна увага зосереджується на аналіз \\ норм, що містяться у Законі України «Про \\ фрахову передвищу освіту», Постанові Кабі- \\ нету Міністрів України від 21 серпня 2019 р. \\ № 800 «Деякі питання підвищення квалі- \\ орікації педагогічних і науково-педагогічних \\ працівників» та положеннях про підвищення \\ кваліфрікації педагогічних працівників, розроб- \\ лених закладами фрахової передвищої освіти. \\ у статmі зазначається, що проаналізовані \\ положення нормативно-правового забезпе- \\ чення порядку організації та здійснення підви- \\ щення квалісрікації у цілому створюють необ- \\ хідні умови для задоволення освітніх потреб \\ у процесі безперервного профресійного розви- \\ тку педагогічних працівників закладів фрахової \\ передвищої освіти. При иьому, незважаючи \\ на нормативне забезпечення, окремі поло- \\ ження щодо порядку організації та здійснення \\ підвищення кваліфікації педагогічних праців- \\ ників закладів фрахової передвищої освіти не \\ до кінця впроваджено в практичну площину. \\ Зокрема, че стосується запровадження \\ дуальної форми організації підвищення квалі- \\ орікації, доступності можливостей удоскона- \\ лення необхідних компетентностей у зару- \\ біжних закладах освіти за рахунок бюджетних \\ коштів, визнання окремих складників інфрор- \\ мальної освіти як заходів із підвищення про- \\ фесійного рівня тощо. \\ Ключові слова: нормативно-правовий акт, \\ педагогічний працівник, підвищення кваліфрі- \\ кації, стажування, професійний розвиток.
}

The article is devoted to the study of the legal support for advanced training and internship of pedagogical employees of professional prehigher education institutions as an integral part of the system of their professional development. It is established, that the current conditions of educational activities cause the need to review traditional approaches to the professional development of pedagogical employees both by the heads of educational institutions and governing bodies in the field of education. The result of this process is the introduction of changes in the current legislation regulating the advanced training and internship of pedagogues, in order to bring it to the requirements of domestic and international legal acts in the field of education.

The main focus is on the analysis of the norms of the Law of Ukraine "On Professional Prehigher Education», the Resolution of the Cabinet of Ministers of Ukraine of August 21, 2019 № 800 «Some issues of advanced training of pedagogical and scientific-pedagogical employees» and Regulations on advanced training of pedagogical employees, worked out by professional pre-higher education institutions. The article outlines, that analyzed provisions of regulatory and legal support for organizing and implementing the advanced training in general create the necessary conditions for meeting the educational needs in the process of continuous professional development of pedagogical employees of professional prehigher education. At the same time, despite the regulatory support, certain provisions concerning the process of organizing and carrying out the advanced training of pedagogical employees of professional prehigher education institutions are not fully implemented into practice. In particular, introducing the dual form of advanced training; availability of opportunities to improve the necessary competencies in foreign educational institutions at the expense of budget funds; recognizing the certain components of informal education as the instruments for improving the professional level, etc.

Key words: regulatory legal act, pedagogical employee, advanced training, internship, professional development.
Постановка проблеми в загальному вигляді. Реформування системи освіти України, зумовлене суспільними глобалізаційними процесами та євроінтеграційними спрямуваннями, детермінує необхідність задоволення потреб суспільства у високопрофресійних освітянських кадрах із відповідною системою цінностей та інноваційним мисленням, спроможних реалізовувати на практиці сучасні досягнення освітньої сорери, готових до ефрективної професійної діяльності в умовах перманентних змін та перетворень.
Сучасні вимоги до організації та здійснення освітнього процесу, особистих та професійних якостей педагога зумовили необхідність перегляду традиційних підходів до професійного розвитку педагогічних працівників як із боку керівників закладів освіти, так і органів управління у сорері освіти. Результатом цього процесу стало внесення змін до чинного законодавства, у тому числі того, що регламентує питання вдосконалення професійних та інших компетентностей педагогів. 
Аналіз останніх досліджень і публікацій. Окремі питання профресійного розвитку педагогічних працівників різних закладів освіти були предметом наукових розвідок вітчизняних учених. Зокрема, професійний розвиток учителя в умовах післядипломної педагогічної освіти досліджувала В. Вітюк; регіональний аспект профеесійного розвитку керівників та педагогічних працівників загальноосвітніх навчальних закладів - Т. Сорочан, А. Данильєв, Б. Дьяченко, О. Рудіна; безперервний професійний розвиток науково-педагогічних працівників у контексті розвитку європейського освітнього простору - М. Ілляхова; зарубіжний досвід професійного розвитку науково-педагогічних працівників у системі післядипломної освіти - Г. Капосльоз, В. Невмержицький, О. Рибчук, О. Розумний та ін.

Виділення не вирішених раніше частин загальної проблеми. Зважаючи на невеликий час, що пройшов від моменту винесення фахової передвищої освіти в окремий складник освіти, а саме прийняття профрільного закону в червні 2019 р., малодосліджуваними залишаються питання щодо особливостей організації та здійснення розвитку професійної компетентності педагогічних працівників фрахових коледжів.

Мета статті. Мета статті полягає у дослідженні правового забезпечення професійного розвитку педагогічних працівників закладів фрахової передвищої освіти.

Виклад основного матеріалу. У наукових колах прийнято вважати, що професійне становлення майбутнього педагога та фрормування в нього ключових професійних компетентностей відбувається під час його навчання в профрільних закладах освіти, що здійснюють підготовку педагогічних працівників.

Водночас із метою задоволення потреб особистості в подальшому професійному розвитку, удосконалення вже сформованих та отримання нових компетентностей, необхідних для ефективного здійснення педагогічної діяльності, в Україні впроваджено концепцію освіти дорослих як складника безперервної освіти впродовж життя. Вона ґрунтується на ідеї постійного усунення невизначеності статусу фрахівця в динаміці пізнавальних і діяльнісних практик протягом усього життя, а також розкритті його креативних ресурсів, що формуватимуть нові горизонти його професійної і особистісно-орієнтованої життєдіяльності [1, с. 57].

Основним результатом професійного розвитку педагогічних працівників $€$ досягнення ними відповідного рівня профресіоналізму, що дасть їм змогу ефективно та на високому рівні здійснювати освітню діяльність відповідно до вимог законодавчих та підзаконних нормативно-правових актів.

При цьому професіоналізм слід розуміти як «...засноване на профресійній самосвідомості та культурі поєднання професійно значущих компетентностей фрахівця, яке забезпечує його здатність і готовність виконувати професійну діяльність на високому рівні» [2, с. 34].

Родовою ознакою поняття профресіоналізму $€$ «поєднання професійно значущих компетентностей», основними 3 яких для педагогічного працівника, на нашу думку, є: професійна, правова, комунікативна, інсоормаційно-комунікаційна, соціальна, психологічна, управлінська, конфрліктологічна та ін.

Якісний професійний розвиток педагогічного працівника можливий за умови гармонійного поєднання формальної, несрормальної та інфрормальної освіти. Це означає, що зміст післядипломної освіти та інших складників освіти дорослих повинен ураховувати сорормовані в процесі профільного навчання компетентності та бути спрямованим на розвиток нових та вдосконалення наявних компетентностей, необхідних для якісного здійснення освітньої діяльності. Розвиток нормативноправового забезпечення освітньої діяльності, педагогічної науки та практики, сучасних інфрормаційних технологій зумовлює виникнення нових освітніх потреб педагогічних працівників, задоволення яких можливе лише в процесі безперервної освіти дорослих.

Ефективним інструментом розвитку означених компетентностей педагогічних працівників економічних коледжів та досягнення ними високого рівня профресіоналізму є система післядипломної освіти.

Науковці зазначають, що сучасна методологія післядипломної профресійної освіти педагогічних працівників ґрунтується на засадах ретроспективного, системного, андрагогічного, акмеологічного, аксіологічного та компетентнісного підходів [2, c. 21].

Окреслені підходи до організації системи післядипломної педагогічної освіти є концептуальними в сучасних умовах та забезпечують досягнення педагогічними працівниками високого рівня професійної, правової та інших компетентностей, необхідних для якісного здійснення освітньої діяльності

Розглядаючи питання професійного розвитку педагогічних працівників закладів фрахової передвищої освіти в умовах післядипломної педагогічної освіти, варто зазначити, що здебільшого вдосконалення відповідних компетентностей педагогів відбувається в системі підвищення кваліфрікації. Відповідно до Закону України «Про фрахову передвищу освіту», вони повинні підвищувати квалісрікацію щорічно. При цьому загальна кількість академічних годин для підвищення квалісрікації впродовж п'яти років не може бути меншою за 120 годин, з яких певна кількість годин має бути спрямована на вдосконалення знань, 
умінь і практичних навичок у роботі зі студентами з особливими освітніми потребами та дорослими студентами. Результати підвищення кваліфікації обов'язково враховуються під час проведення атестації педагогічних працівників та призначення на посаду чи укладення трудового договору [3].

Нормативні вимоги, що стосуються регулювання відносин у цій сорері, деталізуються в «Порядку підвищення кваліфрікації педагогічних і науково-педагогічних працівників», затвердженому Постановою Кабінету Міністрів України від 21 серпня 2019 р. № 800.

Цей підзаконний акт визначає процедуру, види, форми, обсяг (тривалість), періодичність, умови підвищення кваліфрікації педагогічних і науковопедагогічних працівників закладів освіти і установ усіх форм власності та сфер управління, включаючи механізм оплати, умови і процедуру визнання результатів підвищення кваліфікації [4].

Зокрема, у зазначеній Постанові визначено можливості педагогічних працівників закладів освіти незалежно від форми власності під час підвищення кваліфікації самостійно вибирати:

- місце їі проведення (в Україні чи за кордоном);

- фрорму: інституційну (очну (денну, вечірню), заочну, дистанційну, мережеву), дуальну, на робочому місці, на виробництві тощо. Важливий аспект - форми підвищення кваліфрікації можуть поєднуватись між собою;

- вид: навчання за програмою підвищення кваліфікації, у тому числі участь у семінарах, практикумах, тренінгах, вебінарах, майстер-класах тощо та стажування;

- заклад освіти (його структурний підрозділ), наукову установу, іншу юридичну чи фрізичну особу, у тому числі фрізичну особу - підприємця, що провадить освітню діяльність у сорері підвищення кваліфікації педагогічних та/або науково-педагогічних працівників [4].

Окрім того, Постановою також регламентуються вимоги до програм підвищення кваліфікації та стажування, документального офрормлення їх результатів, а також визначаються джерела фрінансування вказаних заходів: кошти державного, місцевих бюджетів, кошти фрізичних та/або юридичних осіб, інші власні надходження закладу освіти та/або його засновника, інші джерела, не заборонені законодавством [4].

Зазначені нововведення суттєво розширюють можливості педагогічних працівників щодо отримання нових та розвитку сорормованих компетентностей, необхідних для ефективного здійснення профресійної діяльності.

Варто зазначити, що заклади фрахової передвищої освіти, ґрунтуючись на розглянутих положеннях чинного законодавства та підзаконних актів щодо підвищення кваліфікації зазначених катего- рій, розробляють власні положення про порядок підвищення кваліфікації педагогічних працівників (далі - положення), які затверджуються керівниками педагогічних рад.

Із метою дослідження порядку організації підвищення кваліфікації педагогічних працівників закладів фрахової передвищої освіти нами проаналізовані відповідні положення, які містяться у відкритому доступі в мережі Інтернет та розроблені у відокремленому структурному підрозділі «Ніжинський фаховий коледж Національного університету біоресурсів і природокористування України2 [5], Закарпатському лісотехнічному коледжі Державного вищого навчального закладу «Національний лісотехнічний університет України» [6], Київському фраховому коледжі комп'ютерних технологій та економіки Національного авіаційного університету [7], Одеському технічному коледжі Одеської національної академії харчових технологій [8], Тернопільському кооперативному фраховому коледжі [9].

За результатами аналізу встановлено, що положення відповідають вимогам законодавчих та підзаконних актів, що регламентують порядок підвищення кваліфрікації педагогічними працівниками закладів фрахової передвищої освіти.

Можемо констатувати, що ці розпорядчі документи мають типову структуру та здебільшого складаються з таких розділів:

1. Загальні положення, де зазначаються правова основа, мета, види (безпосереднє підвищення кваліфікації, стажування, інші види діяльності, що можуть бути визнані як проходження підвищення квалісрікації), фрорми, підходи та вимоги до організації підвищення кваліфрікації педагогічних працівників, а також питання щодо взаємодії із суб'єктами її проведення.

2. Організація підвищення кваліфікації: визначаються основні завдання та напрями цієї діяльності, порядок планування та проходження підвищення кваліфікації педагогічними працівниками, його документального офрормлення.

3. Фінансування підвищення кваліфрікації: деталізуються норми Закону України «Про фрахову передвищу освіту» та Постанови Кабінету Міністрів України від 21 серпня 2019 р. № 800 «Деякі питання підвищення кваліфрікації педагогічних і науково-педагогічних працівників» щодо джерел, порядку та механізмів оплати підвищення кваліфрікації закладами фрахової передвищої освіти, а в окремих випадках, визначених законодавством, - самостійно педагогічними працівниками.

4. Визнання результатів підвищення квалісрікації: визначаються вимоги до документів про проходження підвищення кваліфрікації, порядок звітування про її результати та їх затвердження педагогічними радами фрахових коледжів, а також умови визнання окремих видів діяльності 
(участь у програмах академічної мобільності, наукове стажування, самоосвіта, здобуття наукового ступеня, вищої освіти, а також участь у семінарах, практикумах, тренінгах, вебінарах, майстер-клаcax тощо) як підвищення кваліфрікації.

Основними напрямами підвищення кваліфрікації педагогічних працівників у положеннях [6, с. 4; 7, с. 4; 8, с. 3; 9, с. 3-4] визначено:

- розвиток профресійних компетентностей (знання навчального предмета (дисципліни), фрахових методик, технологій);

- фрормування у здобувачів освіти спільних для ключових компетентностей умінь, визначених частиною першою статті 12 Закону України «Про освіту»;

- психолого-фрізіологічні особливості здобувачів освіти певного віку, основи андрагогіки;

- створення безпечного та інклюзивного освітнього середовища, особливості (специфіка) інклюзивного навчання, забезпечення додаткової підтримки в освітньому процесі дітей з особливими освітніми потребами;

- використання інформаційно-комунікативних та цифрових технологій в освітньому процесі, включаючи електронне навчання, інфрормаційну та кібернетичну безпеку;

- розвиток мовленнєвої, цифрової, комунікативної, інклюзивної, емоційно-етичної компетентностей;

- фрормування професійних компетентностей галузевого спрямування, опанування новітніх виробничих технологій, ознайомлення із сучасним устаткуванням, обладнанням, технікою, станом і тенденціями розвитку галузі економіки, підприємства, організації та установи;

- розвиток управлінської компетентності (для керівників закладів освіти та їхніх заступників) тощо.

Відзначаючи важливість визначених напрямів підвищення кваліфрікації педагогічних працівників фрахових коледжів, на нашу думку, помилковим $€$ відсутність у переліку такого напряму, як розвиток правової компетентності, яка є важливим складником професіоналізму будь-якого керівника чи педагога та дає змогу ефективно здійснювати професійну діяльність відповідно до вимог законодавчих та підзаконних нормативно-правових актів у сорері освіти, а також фрормувати правову свідомість та освіченість учнівської молоді.

Така ситуація створює передумови до зниження рівня правової культури педагогічних працівників, наслідком чого може стати їх неспроможність здійснювати освітню діяльність відповідно до вимог вітчизняних та нормативноправових актів, швидко й безболісно адаптуватися до реформаторських змін в освітній сфері та форомувати необхідний рівень правосвідомості здобувачів освіти.
Важливою умовою безпосереднього підвищення кваліфрікації $€$ врахування законодавчої норми щодо необхідності її проходження щорічно та загального ії обсягу. При цьому кількість годин підвищення кваліфікації в рік, а також питома вага заходів, спрямованих на вдосконалення відповідних компетентностей (наприклад, знань, умінь і практичних навичок у роботі зі здобувачами, які мають особливі освітні потреби), визначається керівництвом фрахового коледжу [5; 6; 8; 9].

Відповідно до проаналізованих положень, стажування як один із видів підвищення кваліфрікації здійснюється 3 метою фрормування і закріплення на практиці професійних компетентностей, здобутих у результаті теоретичної підготовки, щодо виконання завдань і обов'язків на займаній посаді або посаді вищого рівня, засвоєння вітчизняного та зарубіжного досвіду, формування особистісних якостей для виконання професійних завдань на новому, більш якісному рівні в межах певної спеціальності. Воно може здійснюватися в закладах освіти, установах, організаціях та на підприємствах за індивідуальною програмою, яка повинна містити інорормацію про її обсяг (тривалість) та очікувані результати стажування. При цьому один день стажування оцінюється, як правило, в 6 годин, або 0,2 кредиту ЄКТС [5-9].

Висновки. Проаналізовані положення нормативно-правового забезпечення порядку організації та здійснення підвищення кваліфрікації створюють необхідні умови для задоволення освітніх потреб у процесі безперервного профресійного розвитку педагогічних працівників закладів фахової передвищої освіти.

Зокрема, модернізовано відповідну нормативно-правову базу та вживаються заходи з метою приведення ії у відповідність до сучасних вимог вітчизняних та міжнародних правових актів у ссрері освітньої діяльності, суттєво розширено можливості здійснення підвищення кваліфікації та стажування педагогічних працівників, актуалізовано освітньо-профресійні програми відповідних курсів, упроваджено засади компетентнісного навчання у систему освіти дорослих, демонополізовано ринок підвищення кваліфрікації тощо.

Із метою підтримання високого рівня професіоналізму, удосконалення відповідних компетентностей педагогічним працівникам закладів фахової передвищої освіти необхідно комплексно підходити до процесу профресійного розвитку, гармонійно поєднуючи фрормальну, неформальну та індрормальну освіту.

При цьому, незважаючи на нормативне забезпечення, окремі положення щодо порядку організації та здійснення підвищення кваліфрікації педагогічних працівників закладів фрахової передвищої освіти не до кінця впроваджено в практичну площину. Зокрема, це стосується запровадження 
дуальної фрорми організації підвищення кваліфрікації; доступності можливості вдосконалення необхідних компетентностей у зарубіжних закладах освіти за рахунок бюджетних коштів; визнання окремих складників інфрормальної освіти як заходів із підвищення профресійного рівня тощо.

\section{БІБЛІОГРАФІЧНИЙ СПИСОК:}

1. Ілляхова М.В. Безперервний професійний розвиток науково-педагогічних працівників у контексті розвитку Європейського освітнього простору. Вісник Національного університету «Чернігівський колегіум» імені Т.Г. Шевченка. Серія «Педагогічні науки». 2019. Вип. 1. С. 55-60. URL: http://nbuv.gov.ua/UJRN/ vnuchkpn_2019_1_13 (дата звернення: 10.07.2021).

2. Профресійний розвиток керівників і педагогічних працівників загальноосвітніх навчальних закладів у післядипломній педагогічній освіті регіонального рівня (за матеріалами Луганського обласного інституту післядипломної педагогічної освіти) : монографрія / Т.М. Сорочан та ін. Луганськ : СПД Рєзніков В.С., 2013. 524 c.

3. Про фрахову передвищу освіту : Закон України від 06.06.2019 № 2745-VIII. Дата оновлення: 20.03.2020. URL: https://zakon.rada.gov.ua/laws/ show/2745-19\#Text (дата звернення: 04.03.2021).

4. Деякі питання підвищення кваліфікації педагогічних і науково-педагогічних працівників : Постанова Кабінету Міністрів України від 21 серпня 2019 р. № 800. Дата оновлення: 27.12.2019. URL: https:// zakon.rada.gov.ua/laws/show/800-2019-\%D0\%BF\#Text (дата звернення 11.03.2021).

5. Положення про підвищення кваліфрікації педагогічних працівників Відокремленого структурного підрозділу «Ніжинський фаховий коледж Національного університету біоресурсів і природокористування
України», схвалене Педагогічною радою коледжу від 04.01.2021, протокол № 7. URL: https://natc.org.ua/ docs/polozhennya/pol_pro_Pid_kvalifikaciy_2021.pdf (дата звернення: 31.05.2021).

6. Положення про підвищення кваліфікації педагогічних працівників Закарпатського лісотехнічного коледжу Державного вищого навчального закладу «Національний лісотехнічний університет України», затверджене наказом ЗЛТК від 16.10.2020 № 450. URL: https://zltk.com.ua/wp-content/uploads/2020/12/ ПОЛОЖЕННЯ-про-підв.кваліфікації.pdf (дата звернення: 31.05.2021).

7. Положення про порядок підвищення кваліфрікації педагогічних працівників Київського фрахового коледжу комп'ютерних технологій та економіки Національного авіаційного університету, введеного в дію Наказом директора коледжу від 01.09.2020 № 82-1/ОД. URL: http://ccte.nau.edu.ua/Положення/ 16.Положення\%20про\%20підвищення\%20кваліфікації\%20педпрацівників\%20y\%20коледжі.pdf (дата звернення: 31.05.2021).

8. Положення про підвищення квалісрікації та стажування педагогічних працівників Одеського технічного коледжу Одеської Національної академії харчових технологій, затвердженого Педагогічною радою коледжу від 04.12.2019, протокол № 2. URL: https://otfk.od.ua/public_information/provision/files/ polozhennya_pro_pidvyshchennya_kvalifikatsii_ta_ stazhuvannya.pdf (дата звернення: 31.05.2021).

9. Положення про підвищення кваліфрікації педагогічних працівників Тернопільського кооперативного фраховому коледжу, затверджене Наказом директора ТКФК від 13.05.2021 № 48 URL: http:// tktek.te.ua/wp-content/uploads/2021/05/Положенняпро-підвищення-кваліфікації-педагогічнихпрацівників-ТКФК.pdf (дата звернення: 12.07.2021). 